\title{
Analysis of Failure Modes Effect and Criticality Analysis (FMECA): A Stand-Alone Photovoltaic System
}

\author{
Omar Ngala Sarr, Fabe Idrissa Barro, Oumar Absatou Niasse, Fatou Dia, Nacir Mbengue, \\ Bassirou Ba, Cheikh Sene
}

Department of Physics, Faculty of Science and Technology, Semiconductors and Solar Energy Laboratory - Cheikh Anta Diop University, Dakar, Senegal

\section{Email address: \\ sarromarngala@gmail.com (O. N. Sarr)}

\section{To cite this article:}

Omar Ngala Sarr, FABE Idrissa Barro, Oumar Absatou Niasse, Fatou Dia, Nacir Mbengue, Bassirou Ba, Cheikh SENE. Analysis of Failure Modes Effect and Criticality Analysis (FMECA): A Stand-Alone Photovoltaic System. Science Journal of Energy Engineering.

Vol. 5, No. 2, 2017, pp. 40-47. doi: 10.11648/j.sjee.20170502.11

Received: February 24, 2017; Accepted: March 8, 2017; Published: March 27, 2017

\begin{abstract}
This study deals with the implementation of a methodological guide for the maintenance of photovoltaic systems in Senegal. Typical PV systems components are photovoltaic panels, and inverter, a regulator, connecting cables and the battery; so Failure Modes Effect and Criticality Analysis (FMECA) is performed on the PV system in order to increase the reliability and reduce system failures. To do that, a functional analysis of the system through an octopus diagram and a dysfunctional analysis through a fault tree, are used as a decision support for the choice of the coefficients to obtain the full system FMEA. The obtained results allowed us to detect about $40 \%$ of the types of failure that cause over $60 \%$ of system malfunction. Anticipating these types of failure through preventive maintenance would make the PV system more reliable.
\end{abstract}

Keywords: FMECA, Photovoltaic Systems, Maintenance

\section{Introduction}

In the actual context of sustainable development. Renewable energies are undoubtedly an ideal solution from their availability and their perennity. That explains surely all works carried out in renewable energies and particularly photovoltaic. Photovoltaic solar energy represents a factor impossible to circumvent in the race with energies in Africa and particularly in Senegal; however, there is a lack of about maintenance on PV systems. It is then of prior importance to fill this gap. For example, practically $80 \%$ of the photovoltaic street lamps does not function practically more than two to three months. It remains obvious that it is not the solar illumination, which is lacking, but rather a bad installation or a poor maintenance. Moreover this remains also valid for photovoltaic power plant. It is then a great interest to set a system for the maintenance of photovoltaic power plants in Senegal. The main objectives of this work is then to analyze the failure mode in PV systems and then apply FMECA method to set up or improve the maintenance of those systems.

\section{Analysis of the Modes of Failure}

\subsection{The Reliability of a System}

- Reliability

The reliability is the ability of an entity to perform the required functions under stated conditions for a specified time [5]. It is characterized by the probability $R(t)$ the entity $E$ accomplish these functions under the conditions given for the time interval $[0, t]$, given that the entity is not broken at the time $\mathrm{t}=0$, see figure 1 .

$\mathrm{R}(\mathrm{t})=\mathrm{P}[$ E not defaulting on $[0, \mathrm{t}]]$

Reliability is often modeled by:

$$
R(t)=\exp (-\lambda t)
$$

Where $\lambda$ is the failure rate expressed as the percentage of defects 


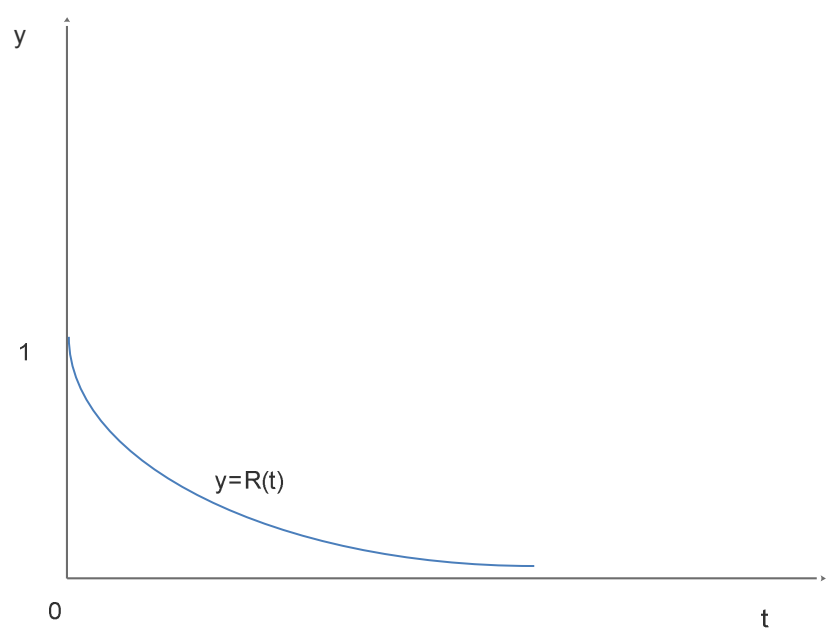

Figure 1. Reliability.

- Availability of a system

Availability is the ability of an entity to be able to accomplish the functions required under the given conditions and at a given time [1]. It is characterized by the probability A (t) of the entity $\mathrm{E}$ at time $\mathrm{t}$, to perform the duties required under given conditions.

$$
A(t)=P[\text { E non-defaulting at time } t]
$$

- Maintainability of a system

Maintainability is the ability of an entity to be maintained or restored to a state in which it can perform a required function, when maintenance is performed under given conditions with prescribed procedures and resources. It is characterized by the probability $M(t)$ the entity $E$ is in state at time $t$, to perform his duties, knowing that the entity was not working at time $\mathrm{t}=0$ [1].

$$
M(t)=P[E \text { is repaired on }[0, t]]
$$

- Safety

Safety is the ability of an entity to avoid, under given conditions, critical or catastrophic events. It is characterized by the probability $\mathrm{S}(\mathrm{t})$ that the entity $\mathrm{E}$ does not let appear in given conditions, critical or catastrophic events.

$\mathrm{S}(\mathrm{t})=\mathrm{P}[\mathrm{E}$ avoids critical or catastrophic events on $[0, \mathrm{t}]]$

- Means reliability time

Figure 2 shows schematically the successive states possible for a repairable system [1].

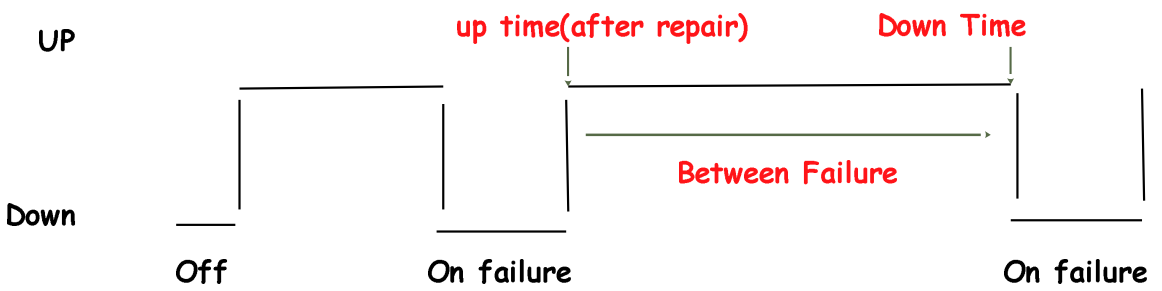

Figure 2. Means reliability time.

In fact, the magnitudes carried by the graph are the durations (TBF) to which there corresponds the means (MTBF) obtained by static operation $m(t)$ or probabilistic $E(t)$ of the $n$ periods recorded and saved. The acronyms used correspond to the following concepts:

- MTTF (Mean Time To Failure)

$$
M T T F=\int_{0}^{\infty} R(t) d t
$$

- MTTR (Mean Time To Repair)

$$
\operatorname{MTTR}=\int_{0}^{\infty}[1-M(t)] d t
$$

- MTBF (Mean Time Between Failures)

$$
M T B F=M D T+M U T
$$

- $\operatorname{MUT}$ (Mean Up Time)

- MDT (Mean Down Time)

\subsection{Failure Rate}

The instantaneous failure rate, $\lambda(\mathrm{t})$ is a feature of reliability. The $\lambda$ value ( $\mathrm{t}) \mathrm{dt}$ is the conditional probability of a failure in the time interval $[\mathrm{t}, \mathrm{t}+\mathrm{dt}]$, knowing that there is no failure in the time interval $[0, t]$. Thus, applying the theorem of conditional probabilities, then $\lambda(\mathrm{t})$ is so that:

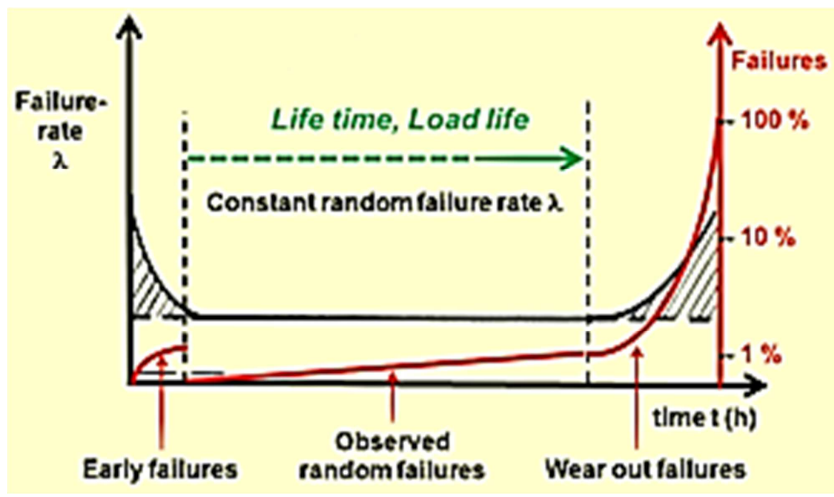

Figure 3. Failure rate.

\subsection{Exponential Distribution}

The exponential distribution is most commonly used in electronics to describe the reliability period during which the equipment failure rate is considered constant (random failure). It describes the elapsed time to failure, or the time interval between two failures. It is defined by a single parameter, the failure rate, $\lambda$. It is characterized by:

- The Reliability:

$$
f(t)=\lambda e^{-\lambda t}
$$


- The probability density:

$$
R(t)=e^{-\lambda t}
$$

- The failure rate:

$$
\lambda(t)=\lambda
$$

$$
M T T F=\frac{1}{\lambda}
$$

\section{The system}

The studied system consists of a solar array connected to a controller, a battery bank and inverter (figure 4)

- MTBF (Mean Time Between Failure):

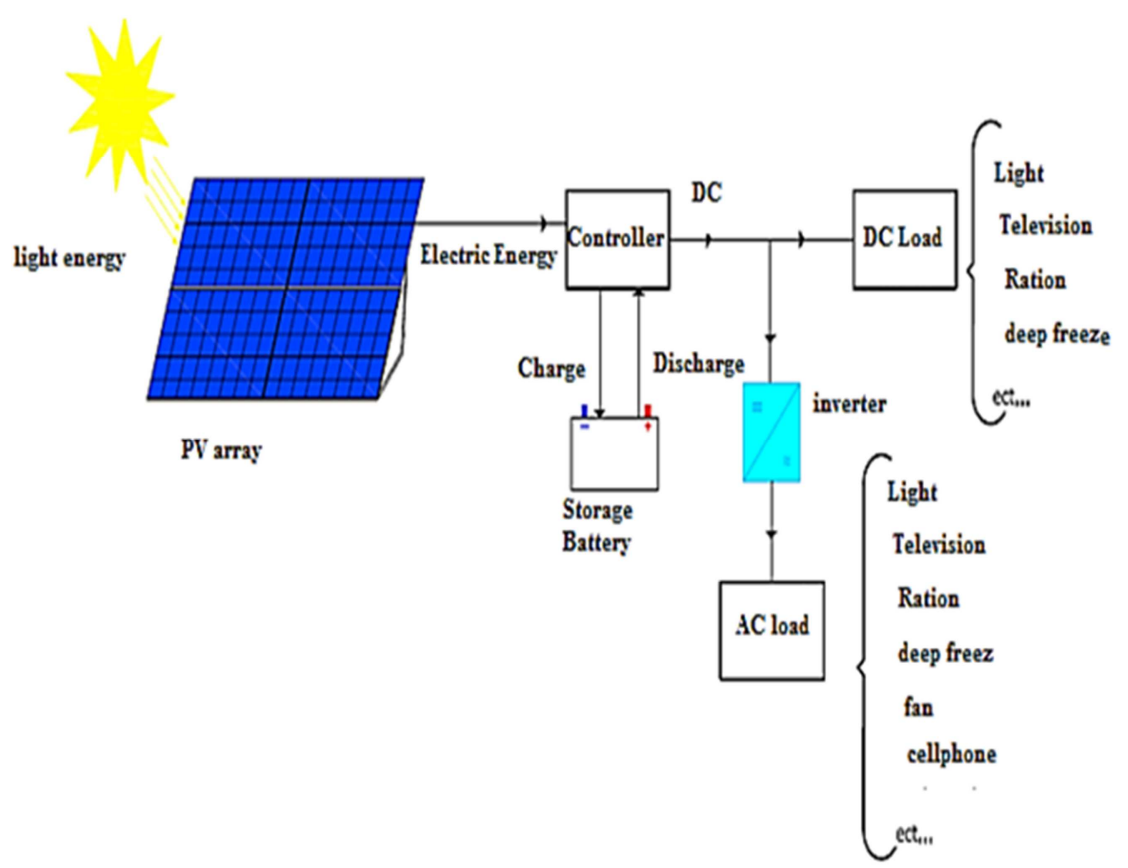

Figure 4. The system.

\subsection{Functional Analysis Through an Octopus Diagram}

The system whose failures are studied must first be "shelled".

What is it used for? What functions does it fulfill? How does it work? Functional analysis must answer these questions rigorously. The system is analyzed under two aspects:

- External: relationships with the external environment.

- Internal: analysis of flows and activities within the process.

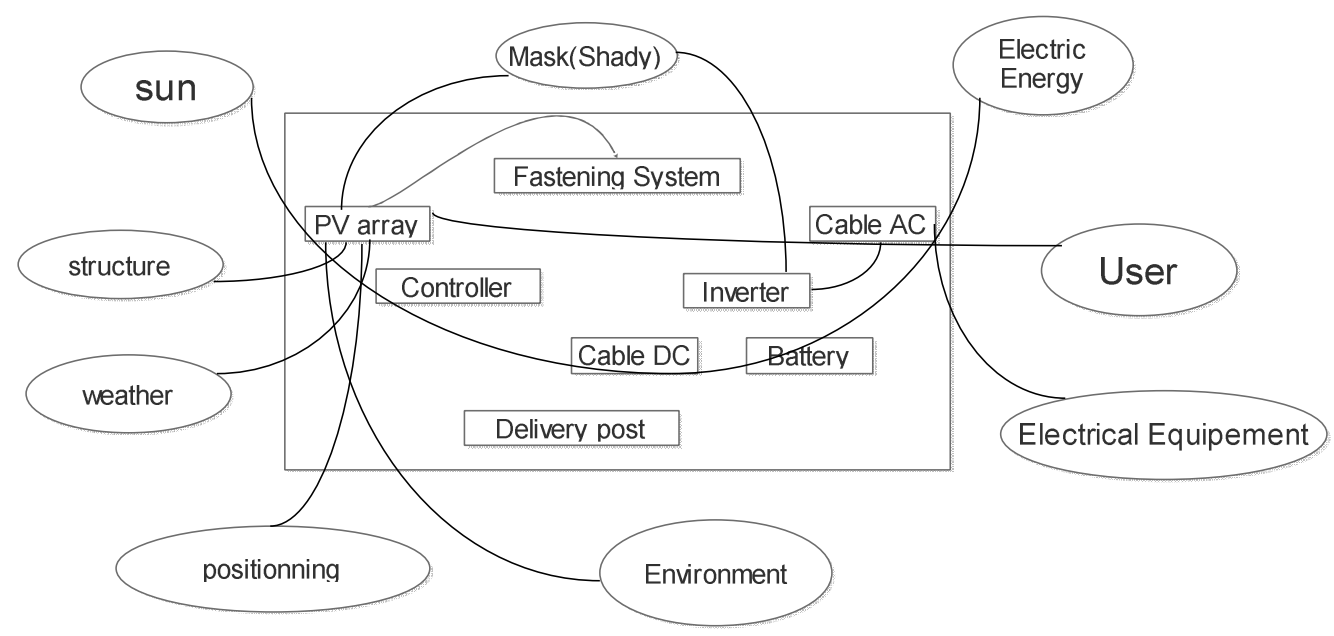

Figure 5. The octopus diagram.

\subsection{Fault Tree Analysis}

The fault tree comprises a plurality of branching describes the probable causes of an event may occur. These events are the result of a number of other events connected by logic "AND" and "Or" gates. 


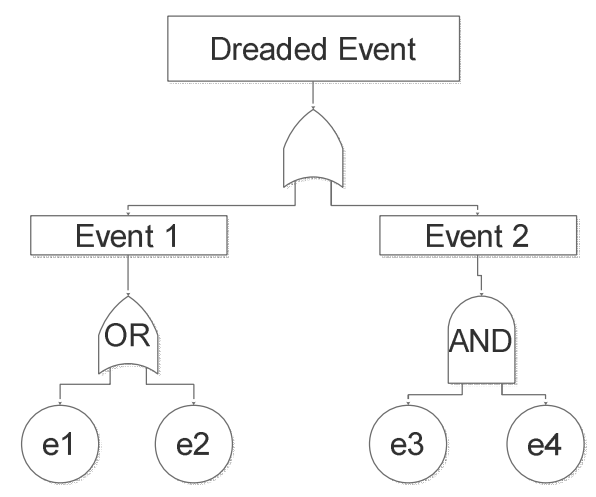

Figure 6. Fault tree connection.
In figure 6 the event E1 resulting from the connection of events e1 and e 2 through an OR gate, can only happen if one of e1 and e 2 occurs well or both events occur simultaneously. Contrary, event E2 will happen only if e3 and e4.

In our system, the feared event is that the PV system does not supply power. There are three major events and their possible causes, which are described by the fault tree. These events include lack of energy output of the AC cable following a minor failure, or following a major failure and lack of energy output of the inverter. These events result from the causes described in the following tree.

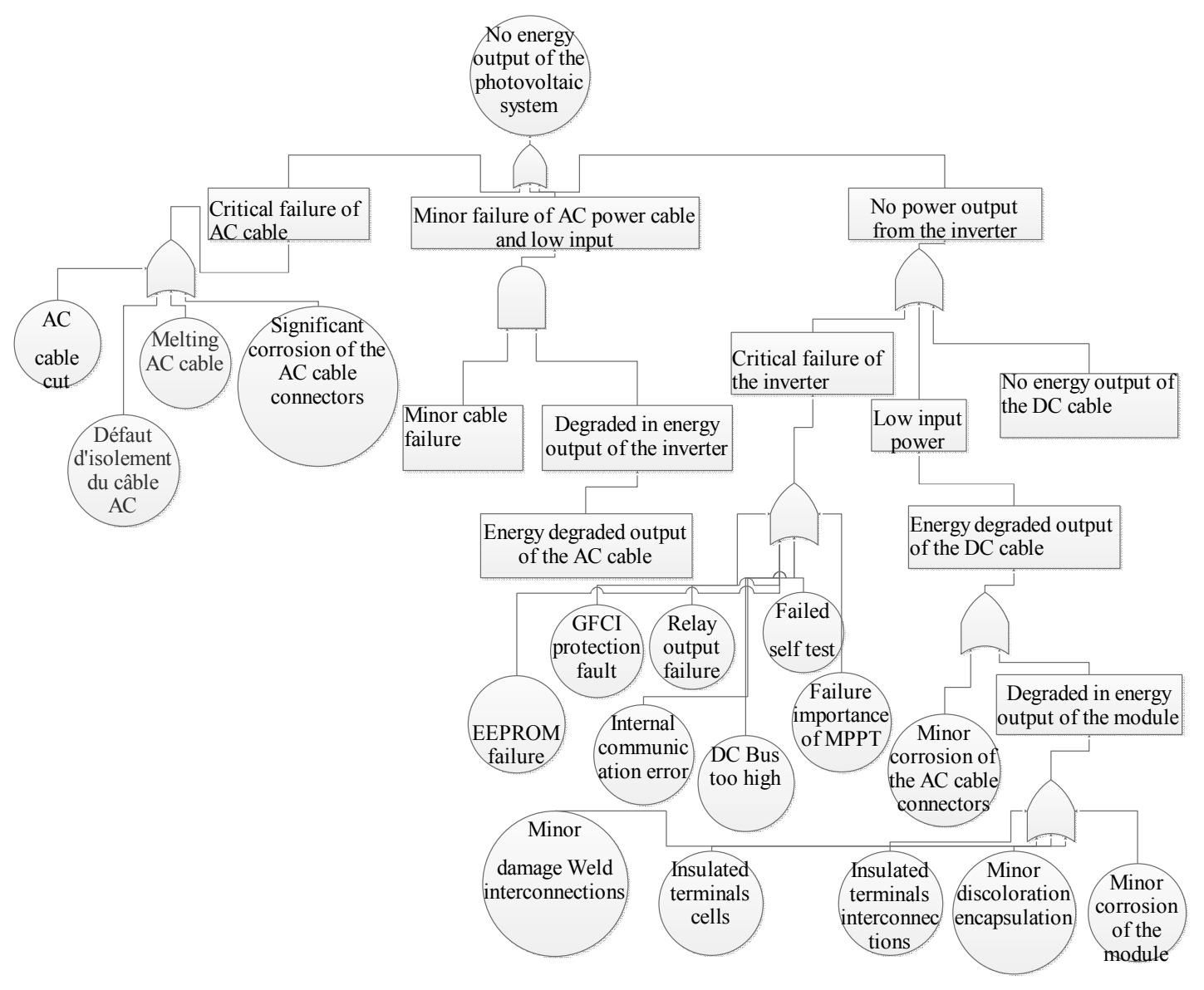

Figure 7. System failure tree.

\subsection{Failure Modes, Effects and Criticality Analysis (FMECA)}

The purpose of the FMECA is to highlight the most critical failures in order to control them. This is an estimation of the criticality index because the trio-mode-effect of potential failure studied according to certain criteria. Several criteria can be used to determine this index. A failure is even more important if:

- The consequences are serious;

- It is quite common;

- If that detection is uncertain

Criticality is the product of the rating assigned to each of the criteria. In this study the notes range from 1 to 10 for each criterion. The allocation of these points is described by the following tables.

- Occurrence

The occurrence is the probability of the failure mode, estimated by answering the question: "What is the relative probability of occurrence of this failure mode?».

Table 1. Occurrence listing.

\begin{tabular}{ll}
\hline Occurrence & occurrence listing \\
\hline Never or rarely appeared & $1-2$ \\
Rarely appeared & $3-4$ \\
That may appear or have appeared & $5-6$ \\
already seen regularly appearance & $7-8$ \\
Almost certain probability of occurrence & $9-10$ \\
\hline
\end{tabular}


- Severity

This is to seek the prioritization of the severity of effects, by answering the question: "What is the relative severity of that effect?».

Table 2. Severity rating

\begin{tabular}{ll}
\hline customer complaints & Severity rating \\
\hline Ineffective or not perceptible effect by the customer & 1 \\
Small inconvenience for the customer & 2 \\
Noticeable discomfort to the client without much too & $3-4$ \\
much inconvenience, the solution can be found quickly & \\
Significant inconvenience perceived by the customer & $5-6$ \\
Total loss of function & $7-8$ \\
Non- compliance & 9 \\
Security problem for the end user customer & 10 \\
\hline
\end{tabular}

- Undetected:

Failure detection is the probability of not detecting the failure mode, by answering the question: «If the failure mode occurs, what is the relative efficiency of detection means in the current or proposed surveillance plan?» We must quoting here the effectiveness of the monitoring plan or control plan, whether actual or proposed.
Table 3. Undetected listing.

\begin{tabular}{ll}
\hline Undetected & Undetected listing \\
\hline Tests and planned trials will some detection & $1-2$ \\
The detection by tests and planned trials is uncertain & $3-4$ \\
Testing and planned tests do not guarantee detection & $5-6$ \\
Detection is difficult & $7-8$ \\
No tests or assays for detection & $9-10$ \\
\hline
\end{tabular}

Calculation of criticality

Simply multiply the three quotations previously allocated for determining priority $\mathrm{C}$ :

$$
C=S \times O \times U
$$

\section{C: criticality \\ S: Severity \\ $\mathrm{U}$ : undetected}

The following table (table 4) shows the calculation of criticality coefficients for each failure mode. The choice is based on the previous tables. In the table, each element of the system is listed, cited his failure mode and the detection mode presented. Criticality is the product of the occurrence, severity and non- detection.

Table 4. Criticality coefficients.

\begin{tabular}{|c|c|c|c|c|c|c|c|c|c|}
\hline \multirow{2}{*}{ Element } & \multirow{2}{*}{ Function } & \multirow{2}{*}{$\begin{array}{l}\text { methods } \\
\text { failures }\end{array}$} & \multirow{2}{*}{ Causes } & \multirow{2}{*}{ Effects } & \multirow{2}{*}{ Detection } & \multicolumn{4}{|c|}{ Criticality } \\
\hline & & & & & & $\mathbf{0}$ & $\mathbf{S}$ & $\mathbf{U}$ & $\mathbf{C}$ \\
\hline \multirow{9}{*}{ PV Module } & \multirow{9}{*}{$\begin{array}{l}\text { Convert solar energy } \\
\text { into electrical } \\
\text { energy }\end{array}$} & \multirow{4}{*}{$\begin{array}{l}\text { The PV module does } \\
\text { not supply electric } \\
\text { power }\end{array}$} & hotspots & \multirow{5}{*}{$\begin{array}{l}\text { The system does not } \\
\text { produce electric } \\
\text { energy }\end{array}$} & \multirow{5}{*}{$\begin{array}{l}\text { Open circuit } \\
\text { voltage } \\
\text { measurement }\end{array}$} & 6 & 9 & 3 & 162 \\
\hline & & & broken Glass & & & 4 & 8 & 4 & 128 \\
\hline & & & Failure of the bypass diode module & & & 3 & 7 & 5 & 105 \\
\hline & & & delamination & & & 4 & 7 & 6 & 168 \\
\hline & & \multirow{5}{*}{$\begin{array}{l}\text { Notorious decrease in } \\
\text { delivered power (less } \\
\text { than the maximum } \\
\text { power) }\end{array}$} & Broken cells / micro cracks & & & 8 & 5 & 7 & 280 \\
\hline & & & Failure of the weld ribbons & \multirow{4}{*}{$\begin{array}{l}\text { The system } \\
\text { produces less or no } \\
\text { electrical energy }\end{array}$} & \multirow{4}{*}{ Visual } & 6 & 7 & 8 & 336 \\
\hline & & & broken interconnections & & & 6 & 6 & 7 & 252 \\
\hline & & & Discoloration of encapsulation & & & 8 & 7 & 7 & 392 \\
\hline & & & Corrosion & & & 8 & 9 & 5 & 360 \\
\hline \multirow{6}{*}{ Inverter } & \multirow{6}{*}{$\begin{array}{l}\text { Transforming } \\
\text { electric power to AC } \\
\text { power }\end{array}$} & \multirow{6}{*}{$\begin{array}{l}\text { The inverter does not } \\
\text { deliver an alternative } \\
\text { electric energy }\end{array}$} & Failure of Microcontroller & \multirow{6}{*}{$\begin{array}{l}\text { The system does not } \\
\text { produce electric } \\
\text { energy }\end{array}$} & \multirow{6}{*}{$\begin{array}{l}\text { visual } \\
\text { indicator }\end{array}$} & 5 & 5 & 8 & 200 \\
\hline & & & Failure GFCI protection & & & 4 & 7 & 9 & 252 \\
\hline & & & Internal communication error & & & 7 & 6 & 7 & 294 \\
\hline & & & Failure of the output relays & & & 4 & 6 & 8 & 192 \\
\hline & & & DC BUS voltage too high & & & 4 & 7 & 8 & 224 \\
\hline & & & Failed Self-Test & & & 6 & 6 & 8 & 288 \\
\hline \multirow{3}{*}{ Cable } & \multirow{3}{*}{$\begin{array}{l}\text { Ensure the flow of } \\
\text { electricity }\end{array}$} & \multirow{3}{*}{$\begin{array}{l}\text { The electrical energy } \\
\text { is not transmitted } \\
\text { The transmitted power } \\
\text { is low }\end{array}$} & cable cut & \multirow{3}{*}{$\begin{array}{l}\text { The system does not } \\
\text { produce electric } \\
\text { energy }\end{array}$} & \multirow{3}{*}{ Visual } & 5 & 7 & 2 & 70 \\
\hline & & & melting cable (UV, heat,...) & & & 4 & 9 & 6 & 216 \\
\hline & & & Corrosion of connectors & & & 6 & 7 & 2 & 84 \\
\hline \multirow{3}{*}{ Battery } & \multirow{3}{*}{$\begin{array}{l}\text { Store energy for a } \\
\text { return to the system }\end{array}$} & \multirow{2}{*}{ sulfation } & repetitive discharge & \multirow{2}{*}{$\begin{array}{l}\text { The battery does not } \\
\text { restore energy }\end{array}$} & \multirow{2}{*}{ Visual } & 8 & 9 & 4 & 288 \\
\hline & & & $\begin{array}{l}\text { Hardening of lead sulfate crystals of } \\
\text { electrodes }\end{array}$ & & & 6 & 7 & 4 & 168 \\
\hline & & $\begin{array}{l}\text { Drying of the } \\
\text { electrolyte }\end{array}$ & $\begin{array}{l}\text { Evaporation or leakage of } \\
\text { electrolyte }\end{array}$ & $\begin{array}{l}\text { The battery does not } \\
\text { restore energy }\end{array}$ & Visual & 7 & 8 & 3 & 168 \\
\hline & Regulate the & & Faulty control unit & & $\begin{array}{l}\text { indicator } \\
\text { light }\end{array}$ & 4 & 7 & 5 & 140 \\
\hline Regulator & $\begin{array}{l}\text { charging and } \\
\text { discharging of the } \\
\text { battery for }\end{array}$ & $\begin{array}{l}\text { The controller does } \\
\text { not control the } \\
\text { charging and }\end{array}$ & The transistor does not work & $\begin{array}{l}\text { the battery is not } \\
\text { loaded properly }\end{array}$ & $\begin{array}{l}\text { Global } \\
\text { measurement } \\
\text { parameters }\end{array}$ & 4 & 4 & 8 & 128 \\
\hline & protection of both & discharging & Blown fusible & & Visual & 3 & 3 & 2 & 18 \\
\hline & battery and loads & & Failure of MPPT & & $\begin{array}{l}\text { voltage } \\
\text { measurement }\end{array}$ & 3 & 5 & 7 & 105 \\
\hline
\end{tabular}


For a more detailed overview of the calculation, each element will be studied separately and Pareto study will locate types of failure on which the priorities will be.

\section{Analysis of Results of the FMECA Study of the System}

Calculating coefficients allowed to find for each item different types of failure and their values in terms of criticality.

\subsection{Criticality of Cable}

The figure 8 shows the mapped criticality for the Cable.

\section{Criticality of the elements of the Cable}

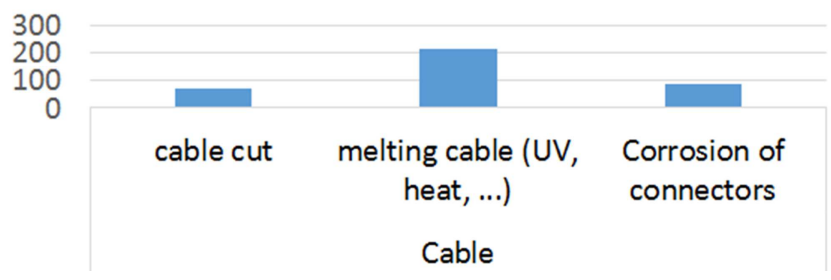

Figure 8. Criticality of the cable elements.

For the cables, the listed potential failure are breaking, melting or corrosion of connectors. Greater relative criticality is noted to melting cables that combines a total of 216 points.

\subsection{Criticality of the Elements of the Inverter}

The figure 9 shows the criticality traced for the inverter.

Criticality of the elements of the Inverter

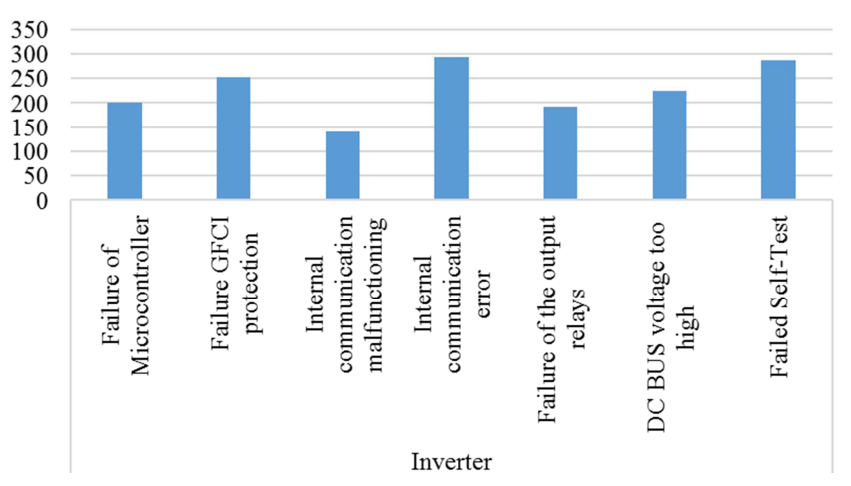

Figure 9. Criticality of the elements of the Inverter.

The inverter includes alone about seven opportunities failures. The internal communication error, the failure of GFCI protection and the failed self-test total respectively 294, 252 and 288 points on the criticality level.

\subsection{Criticality of the Elements of the Battery}

The figure 10 is a graphical representation of criticality for the battery.

\section{Criticality of the elements of the Battery}

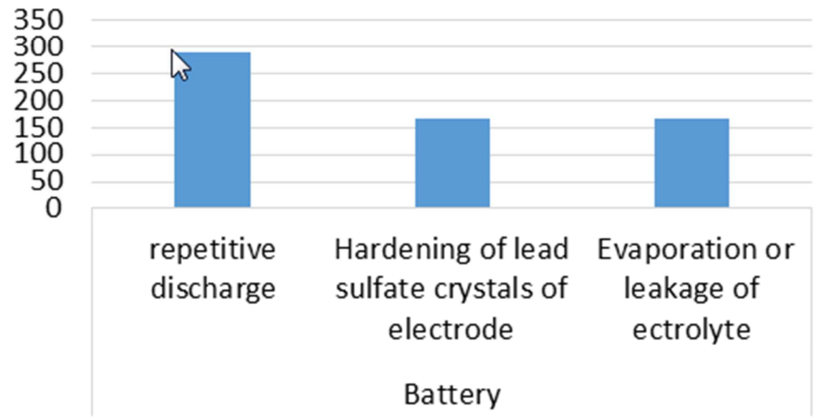

Figure 10. Criticality of the Battery elements.

The three failure modes chosen for the battery are repetitive discharges, sulfating and evaporation or leakage of the electrolyte. Their critical points exceed 150 points.

\subsection{Criticality of the Elements of the Regulator}

\section{Criticality of the elements of the Regulator}

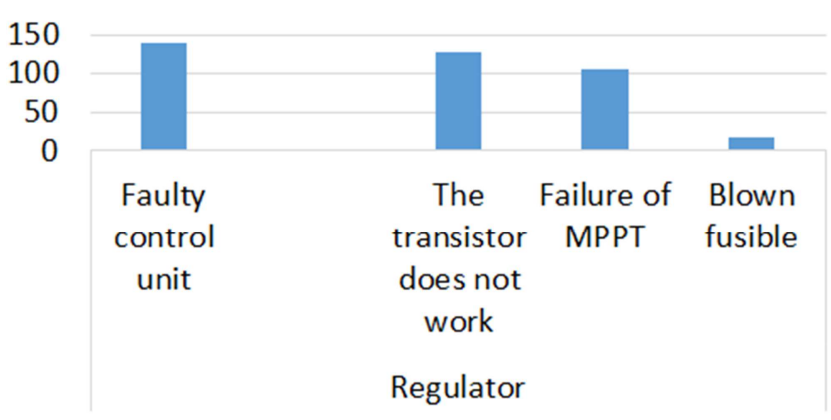

Figure 11. Criticality of the elements of the Regulator.

The figure 11 shows the criticality map of the regulator For the regulator, the faulty control unit has the highest criticality with 140 followed by the transistor which combines a total of 128 each.

\section{Discussion}

The figure 12 shows the criticality diagram for the system by highlighting the criticality threshold giving priority to certain failure modes. 


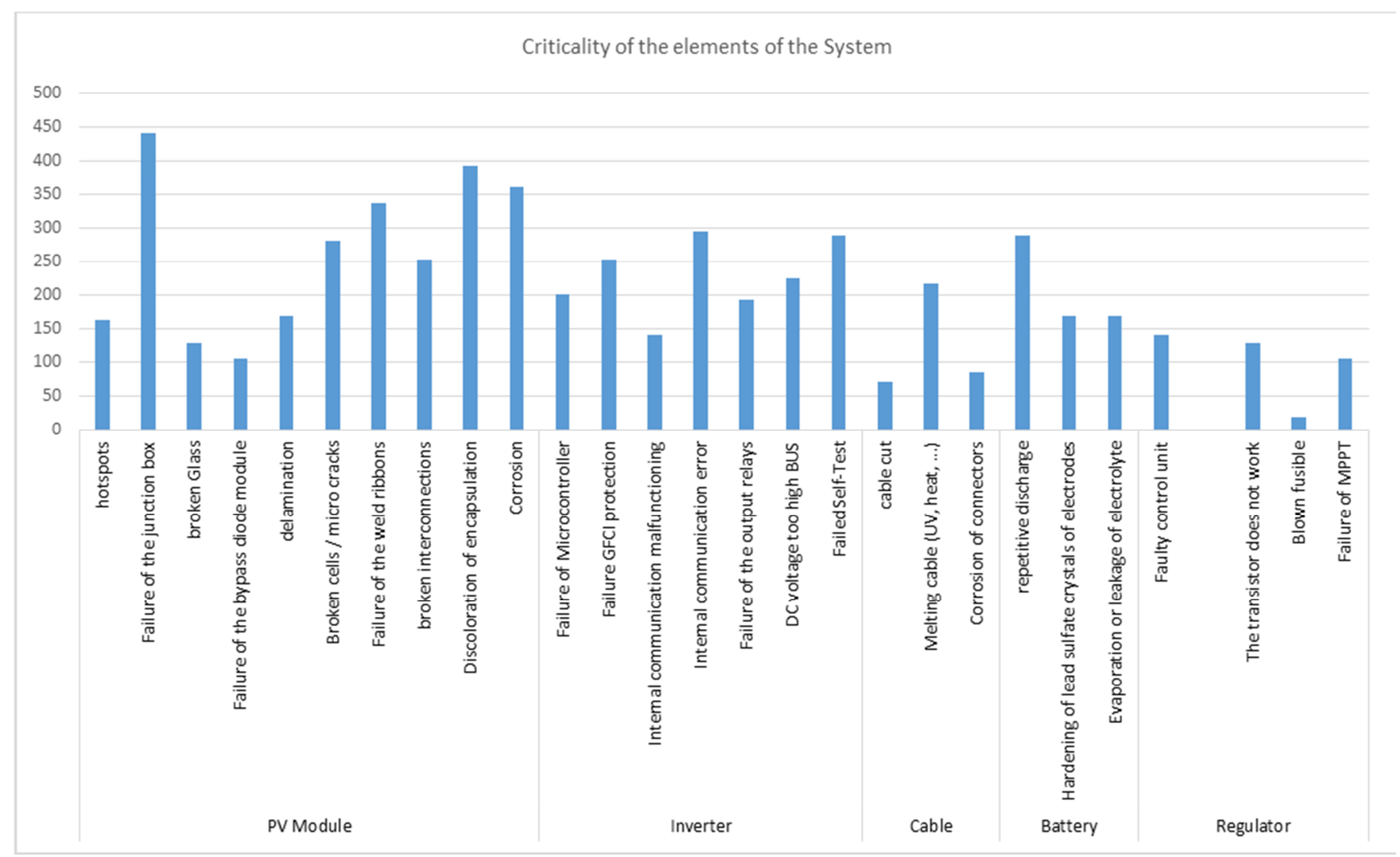

Figure 12. Criticality of the elements of the System.

Pareto Criticality Analysis of system failures

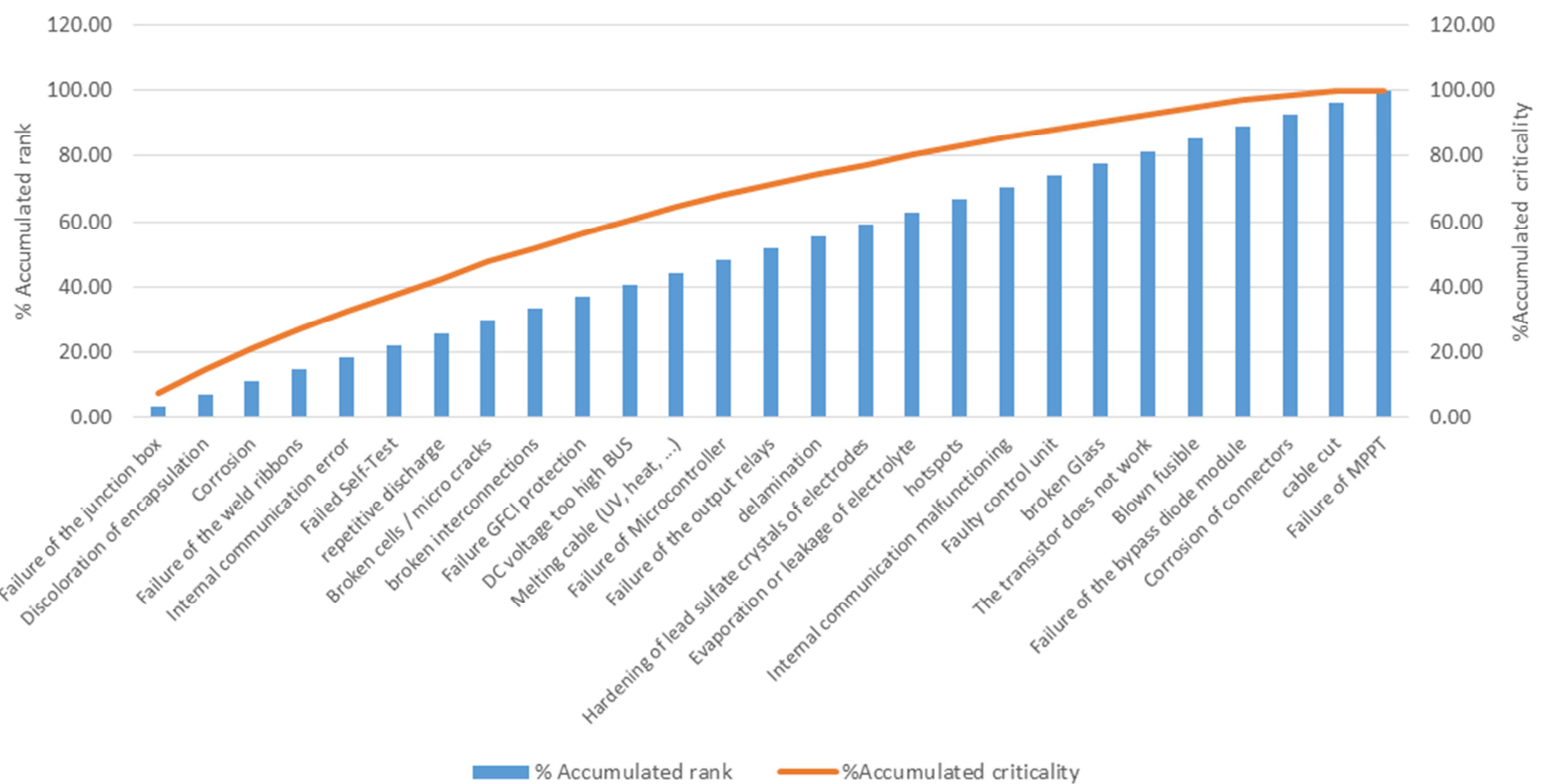

Figure 13. The Pareto curve.

Analysis of system failures shows a shared distribution of the criticality of the system elements. A threshold of two hundred (200) has been set. Failures whose criticality is less than 200 do not create any particular problem in that. They are easily identifiable, are infrequent or not too bad for the system.
Criticality includes a product consisting of case, the probability of non-detection and severity of a type of failure. Failures whose criticality exceeds the threshold (200) deserve special attention. This attention will result in preventive maintenance to deal with any eventuality on. 
For better visibility, a Pareto analysis was performed.

Pareto analysis

The Pareto analysis allows to see the minimum of causes that leads to maximum effect on the system. Figure 13 represents the Pareto curve. For the draw, a ranking of failure modes has been achieved in decreasing order, and a percentage was calculated through the combination of criticality.

The Pareto analysis shows that $40 \%$ of failures makes over $60 \%$ of the criticality cumulating. In this $40 \%$ we find for the battery failures, the repetitive discharge and for photovoltaic panels, among other failures we have the broken interconnections. And finally to the failure modes of an inverter may be mentioned the failure of microcontroller and the overvoltage of the BUS.

A mastering of these failure modes ( $40 \%$ of the total) could reduce by $60 \%$ the system crashes and contribute strongly to the reliability of autonomous photovoltaic systems.

\section{Conclusion}

The study focused on maintenance of autonomous photovoltaic systems. After a reminder of the exponential law, a functional analysis of the system was made through an octopus diagram and a fault tree. This was done in order to help us choose the criticality coefficients through the Failure Modes Effects and criticality Analysis (FMECA). A Pareto study applied to the system showed that $40 \%$ of possible failures themselves include nearly $60 \%$ of the criticality of the system. Mastering these failures will increase the reliability of the entire autonomous photovoltaic system.

\section{References}

[1] Monchy, François, Vernier Maintenance: Méthodes et organisations Ed. 3, Dunod 2010 page 140-141.

[2] M. V'azquez, C. Algora, I. Rey-Stolle et J. Gonza'lez. "III-V concentrator solar cell reliability prediction based on quantitative LED reliability data". Progress in Photovoltaics: Research and Applications, Vol. 15, No. 6, pp. 477-491, 2007.

[3] Lyonnet, Patrick, Fiabilité industrielle: La boîte à outils des processus de fiabilité et maintenance AFNOR 2016.

[4] A. Labouret et M. Villoz. "Energie solaire photovoltaïque". 4e Ed., 2009.

[5] Heng, Jean, Pratique de la maintenance preventive, Dunod 2011 page 17.

[6] H. Liao et E. Elsayed. "Reliability prediction and testing plan based on an accelerated degradation rate model". International Journal of Materials and Product Technology, Vol. 21, No. 5, pp. 402-422, 2004.

[7] Antonio Luque, Steven Hegedus, "Handbook of Photovoltaic Science and Engineering", 2003.

[8] Gillet-Goinard, Florence, Monar, Christel, "Toute la fonction QSSE (Qualité/Santé/Sécurité/ Environnement): Savoir/ Savoir-faire/ Savoir être", Dunod 2013.

[9] Landy, Gérard, "AMDEC: Guide pratique”, AFNOR 2011.

[10] Rémi LARONDE, Thèse de Doctorat: Fiabilité et durabilité d'un système complexe dédié aux énergies renouvelables Application à un système photovoltaïque.

[11] Labib, Ashraf, "Learning from Failures: Decision Analysis of Major Disasters", Elsevier Science, 2014. 